DOI https:// doi.org/10.32837/app.v0i67.1152

УДК 323.2:004(477)

T. М. Краснопольська

orcid.org/0000-0001-5936-5889

кандидат політичних наук, доцент,

доцент каредри політичних теорій

Національного університету «Одеська юридична академія»

I. М. Милосердна

orcid.org/0000-0003-2083-9500

кандидат політичних наук, доиент,

доцент кафедри політичних теорій

Національного університету «Одеська юридична академія»

\title{
ЦИФРОВІ ТЕХНОЛОГІЇ В МЕХАНІЗМІ ВЗАСМОДІЇ ГРОМАДЯНСЬКОГО СУСПІЛЬСТВА ТА ДЕРЖАВИ
}

Ефективна взаємодія держави та громадянського суспільства сприяє суспільному розвитку та становленню принципів демократії. Тому важливим предметом дослідження є механізм такої взаємодії в умовах становлення інформаційного суспільства та використання цифрових технологій. Останні дають нові можливості налагодження комунікації громадянського суспільства, його інститутів та окремих громадян з органами влади та управління, а також демонструють проблемні аспекти використання таких технологій на різних етапах інтеракції суспільства та держави.

Слід зазначити, що останнім часом значно зростає науковий інтерес до громадянського суспільства. Це пов'язано з демократичними змінами світової спільноти та поширенням новітніх інформаційних технологій. Ліберальні демократи дотримуються думки, що громадянське суспільство - це захисна структура індивіда від держави, ідеалом якої є максимальна свобода і незалежність індивідів та інститутів цього суспільства. Соціал-демократи, які прагнуть до створення системи громадської рівноваги, розглядають його як ядро всього суспільного і політичного життя. Суспільство може бути демократичним, якщо у нього буде можливість формувати структури влади, які і визначають контури громадянського суспільства. Вони визнають певне втручання в життя громадянського суспільства для того, щоб запобігти експансіонізму будь-якої частини його.

Американський політолог І. Шапіро у своїй доповіді на конференції в 1992 році висловив думку про те, що демократія не є єдиним або вищим благом держави. Вона найбільш ефективна тоді, коли «структурує людську діяльність, не визначаючи цим ії̈ протікання» (Краснова, Зорина, Киреенкова, Кортунов, 2019, с. 96).

Особливістю сучасного громадянського суспільства є зростаюча популярність соціальних мереж, інтегрованих на основі Інтернету. Вони доповнюються можливостями мобільного телефонного зв'язку, завдяки чому групи громадян, асоційовані за інтересами в віртуальному інформаційному середовищі, реалізують свої комунікативні потреби. Мережеве суспільство і його практики багато в чому визначають хід демократичних процесів, культурні трансформації, самовизначення особистості. 3 початком цифрової епохи, на думку T.I. Фролової, як локальні громадські організації, так і планетарні цивільні мережі отримали потужний комунікативний ресурс для демократичних ініціатив і самоорганізації (Фролова, 2014, с. 29). Користувачі мережі, що станом на кінець 2020 року становлять 64,7\% населення планети (World Internet Users Statistics, 2021), - це розгалужена комунікаційна структура, оснащена «smart mobs», яка прискорює соціальні трансформації і перетворюється в головний ресурс формування глобального громадянського суспільства.

Соціокультурні особливості, привнесені мобільною комунікацією, стали об'єктом уваги вчених різних галузей науки - теоретиків масової комунікації та журналістики, політологів, соціологів, культурологів, антропологів тощо. М. Кастельс всебічно досліджував тему «мере- 
жевого суспільства» як фундамент сучасної економіки, політики і культури. Як провідний теоретик інформаційного суспільства вчений продовжує досліджувати систему найскладніших взаємодій між інформаційними технологіями, економічною діяльністю, культурним та соціальним життям сучасного постіндустріального світу. На думку дослідника, мережева комунікативна структура відображає тип мислення і спосіб життя індивідуумів, що знаходяться в умовах розвинутого інформаційного суспільства (Castells, 2003; 2004; 2009).

Ефективність громадянського суспільства, на думку Ю.В. Ірхіна, можна визначити, оцінюючи те, як об'єднання громадян виконують такі функції: здійснення організаціями та асоціаціями громадян, а також окремими представниками громадянського суспільства контролю над діяльністю держави, посадових осіб і адміністративних структур; участь інститутів громадянського суспільства в законотворчому процесі на всіх його стадіях; партнерство з державою і бізнесом щодо забезпечення вільної конкуренції та інших імперативів розвитку ринкової економіки; активність недержавних засобів масової інформації у висвітленні діяльності держави; функціонування експертних спільнот як референтних груп за оцінкою прозорості та ефективності діяльності держави та їі органів; функціонування органів місцевого самоврядування, формування концепції місцевого менеджеризму: надання послуг і вирішення конкретних проблем на рівні місцевої громади громадян $з$ орієнтацією на конкретного споживача - місцевого жителя; незалежна оцінка та моніторинг діяльності органів влади, ведення роз'яснювальної роботи серед населення для залучення громадян до незалежної та об'єктивної оцінки ефективності адміністративного апарату міста і регіону; здійснення незалежного аудиту ефективності витрачання бюджетних асигнувань, субсидій, грантів; контроль дотримання прав людини і конституційних прав громадян бюджетними організаціями (лікарнями, навчальними закладами тощо), органами внутрішніх справ тощо; взаємодія з міжнародними організаціями та арбітражами тощо. (Ирхин, 2010, с. 12-13).

Цей список слід доповнити функціями агрегації та артикуляції інтересів, а також громадянської соціалізації індивідів, оскільки вони створюють умови, за яких «у відкритому зіставленні поглядів відбувається «притирання» різних груп інтересів і в діалозі з державною владою формується громадянська свідомість і громадянська позиція» (Растимешина, Антонов, 2019, с. 172).

Однією з ознак громадянського суспільства є можливість вільно висловлювати свою думку. Основним майданчиком для цього $є$ Інтернет. Саме він і соціальні мережі $є$ механізмом ефективного використання громадянської активності, мобілізації громадських активістів. Активність в Інтернеті характеризується анонімністю, різнорідністю і динамізмом, володіє масштабністю і адаптивністю. Спосіб прояву оперативний, оскільки свою думкуу можна відразу поширити на багатомільйонну аудиторію, не погоджуючи свої дії з владою. Влада також стала надавати важливого значення інформації, одержаній з Інтернету, щодо актуальних для громадян тем, які вимагають реагування. Однією з найпопулярніших форм прояву громадянської активності в Інтернеті є збір підписів під петиціями. Електронні підписи привертають увагу широкої громадськості. В Україні форма колективного звернення громадян до Президента, Верховної Ради, Кабінету Міністрів і органів місцевого самоврядування стала поширеною. Так, електронні петиції до уряду можна подати за допомогою сайту petition. kmu.gov.ua, до органів місцевого самоврядування - через сайт Єдиної системи місцевих петицій - dem.in.ua і т.п. Глобальна мережа стала місцем різних суспільно-політичних дискусій, простором вираження поглядів представників різних соціальних груп, що дозволяє подолати ієрархічність суспільних структур. Головний принцип мережі Інтернет - відкритість, в будьякий момент будь-яка людина може стати свідком подій в будь-якій точці землі, знати думку людей по всьому світы. Подібного інструменту громадянське суспільство ще не знало, і саме в ньому полягає майбутнє останнього (Краснова, Зорина, Киреенкова, Кортунов, 2019, с. 97). Завдяки мережі Інтернет політичні процеси і управління набули нового змісту, що зумовило появу нових суб'єктів громадянського суспільства - мережевих спільнот як відносно нестійких сукупностей людей, що взаємодіють за допомогою системи комунікацій, які забезпечуються службами мережі Інтернет, що володіють спільністю інтересів і здійснюють спільну діяльність у віртуальному просторі. Вони сприяють формуванню «мережевого громадянського суспільства», мета якого - спілкування в режимі он-лайн для вирішення соціальних проблем. 
Головними характеристиками мережевого громадянського суспільства є «відкритість» («встановлення широких, багатовимірних зв'язків комунікації») і «спонтанність» («вільне формування, плинність, постійна зміна структури»); під впливом мережевих технологій формується ореn space-простір, в якому відкриваються нові можливості для розвитку громадянського суспільства (подолання відчуженості, нерозвиненості комунікацій) (Белянцев, Лымар, 2012, с. 286). Перенесення громадських структур у віртуальний простір сприяє більш продуктивній взаємодії органів влади та громадян. Тут важливо згадати концепцію «цифрової демократії», яка являє собою мережеву взаємодію громадян і політичних акторів в прийнятті рішень, тобто мережева громадськість отримує можливість впливати на формування та реалізацію публічної політики. Практичне вираження «цифрової демократії» - технологія «GOV 2.0» або «уряд 2.0», яка грунтується на принципі відкритості влади та участі громадян в прийнятті рішень на всіх рівнях. Така технологія реалізується через прихід чиновників в соціальні мережі і блогосферу, просвіту спільнот, де ведеться дискусія з громадянами, є доступ до діючих і тих, що перебувають в роботі, законів в режимі онлайн і інші мережеві практики (Быков, 2010, с. 29).

Комунікації в рамках соціальних мереж є більш швидким і ефективним інструментом, ніж «вертикальна» комунікація, здійснювана державними каналами. Крім того, мережеві спільноти найбільш швидко сприймають інновації у сфері Інтернет-технологій. Поряд з уже традиційними технологіями (електронна пошта, www, мультимедіа, комплекс технологій Social Software, мережеві платіжні системи, он-лайн голосування, миттєвий обмін повідомленнями та ін.), А.Е. Белянцев та А.В. Лимар визначають такі, як: Network Democracy («мережева демократія») - технологія колективного прийняття рішень організацій громадянського суспільства та урядових структур на основі прозорості та відкритої порядку денного; Social Bar - технологія, що дозволяє ділитися новинами з друзями в соціальних мережах, що дає можливості для структурування мережевих спільнот та їх мобілізації; Global Voices Online - міжнародне співтовариство добровольців, які переводять, підсумовують і висвітлюють теми, що обговорюються по всьому світу в блогах, відеоблогах і сайтах обміну фотографіями, що дозволяє отримувати вільну та актуальну інформацію про події в будь-якій точці земної кулі (Белянцев, Лымар, 2012, с. 287).

Отже, соціальні мережі (сюди ж можна включити блоги, форуми, онлайн ЗМІ) стають важливим інструментом формування громадянського суспільства, головним чинником його самоорганізації і громадянської мобілізації під впливом зовнішніх обставин (наприклад, в умовах надзвичайних ситуацій та природних катастроф), а також майданчиками для взаємодії влади і громадян (Быков, 2010, с. 30).

Звертаючись до складників механізму взаємодії громадянського суспільства та держави, варто погодитись із думкою П.В. Кузьміна, що важливим елементом такого механізму є принципи, які проголошуються, визнаються і використовуються суб'єктами взаємодії. До основних принципів автор відносить: відкритість; взаємоповагу і визнання специфічних особливостей кожної зі сторін; знання і розуміння цілей і завдань одне одного; збалансований взаємоконтроль, взаємне обмеження і взаємодопомога державних і недержавних органів та організацій; відповідальність за виконання прийнятих рішень; правове регулювання взаємовідносин; принцип конкурсності під час визначення партнерів на участь в спільних програмах, отримання державних грантів, соціальних замовлень (Кузьмін, 2013, с. 28).

Як показує практика західних країн, взаємодія державних органів і громадських інститутів здійснюється за низкою напрямів: забезпечення для громадських об'єднань режиму відкритості розроблення і здійснення програм соціальної політики; налагодження інформаційного обміну (особливо у сфері реалізації прав і свобод громадян); вироблення механізмів державної підтримки соціально значущих ініціатив інститутів громадянського суспільства; розвиток практики залучення громадських об'єднань до виконання соціальних програм на контрактній основі (Томас, 2000, с. 34).

Використання цифрових технологій є важливим елементом інтеракції суспільства та держави на всіх іiі етапах і рівнях. Механізм такої взаємодії, на думку 3.М. Зотова, може мати кілька рівнів: рівень комплексного аналізу проблеми (з'ясування змісту проблеми, іï впливу на розвиток подій; визначення можливих учасників взаємодії; взаємне інформування можли- 
вих партнерів з усіх аспектів проблеми; з'ясування фінансових можливостей партнерів щодо вирішення проблеми); рівень розробки системи заходів і проектів програм (на цьому рівні пріоритетне місце належить державним органам); рівень прийняття рішень; рівень реалізації спільно прийнятого рішення; рівень контролю і перевірки виконання рішення, оцінки ефективності взаємодії сторін (Зотов, 2001, с. 207-208).

На кожному з зазначених рівнів має місце використання новітніх інформаційних технологій та інструментів електронної політичної участі. Саме остання стає все більш потужним засобом громадянського суспільства у відносинах із державою. Перший рівень забезпечується через функціонування електронних майданчиків для обговорення проблем, можливостями зворотного зв'язку через офіційні сайти органів публічного управління, проведення громадських обговорень, організацію тематичних груп в соціальних мережах тощо. На другому рівні важливими інструментами стають публічні обговорення та функціонування громадських рад. Цифрові технології відіграють ключову роль у першій групі інструментів. Одним з яскравих прикладів є досвід Ісландії, що використала мережу Інтернет, а саме соціальні мережі фейсбук, твіттер, YouTube i Flickr (Как создается и работает электронная демократия, 2018), на другому рівні взаємодії держави та громадянського суспільства для обговорення проекту конституції. В результаті при формуванні проекту конституції було враховано офіційні пропозиції та коментарі в соціальних мережах.

Громадські ради виконують важливу роль і для забезпечення участі громадян у політичному процесі, і для підвищення легітимності й ефективності політики через залучення потенціалу й досвіду громадськості. Але варто відзначити, що ефективність таких інститутів $є$ недостатньо високою. Дослідники вважають, що проблема полягає в способі формування і недостатній кількості експертів в них (Ціммерман, 2005, с. 271). Т. Андрійчук пропонує формувати два типи рад: експертні (до яких входитимуть відібрані органом виконавчої влади експерти) та власне громадські, що «об'єднуватимуть представників громадськості, що не $є$ фахівцями у сфері діяльності конкретного органу, але водночас $є$ виразниками інтересів певних груп населення (Розвиток взаємодії, 2013, с. 359).

Прийняття рішень в умовах інформаційного суспільства передбачає залучення громадянського суспільства за допомогою «мережевої демократії». Ще одним прикладом використання цифрових технологій на даному рівні $є$ проведення виборів шляхом електронного голосування. Врахування думки громадськості призводить до того, що політичні процеси на рівні реалізації є більш ефективними.

Останній, п' ятий, рівень є одним 3 найбільш важливих, оскільки дає можливість оцінити результат, визначити сильні та слабкі сторони, зробити прогноз на майбутнє та відкоригувати політику на національному, регіональному, локальному рівні. Громадський контроль забезпечує законність діяльності органів влади. Реалізація таких форм контролю, як проведення громадського моніторингу, громадських обговорень, громадських (публічних) слухань та ін., спрощується під час використання цифрових технологій як у часовому, так і в територіальному аспекті і підвищує їх репрезентативність.

На думку І.В. Гончарова, реалії сучасного цифрового світу такі, що новизна і швидкість поширення і впровадження інформаційних технологій здатні: «по-перше, забезпечити великі можливості для врахування думки користувачів інтернет-ресурсів в діяльності органів державної влади; по-друге, забезпечуючи рівний доступ користувачів до інформаційних ресурсів, цифрові технології зумовлюють фактичне використання суспільством інтерактивних можливостей для організації контролю за діяльністю відповідних органів влади, а значить, забезпечують реальну участь індивіда в управлінні справами держави» (Гончаров, 2019, с. 2425). Отже, тим самим суспільні очікування і запити задовольняються, забезпечується високий рівень довіри населення до влади, тобто відбувається забезпечення реальної дії ст. 5 Конституції України, відповідно до якої «носієм суверенітету і єдиним джерелом влади в Україні $є$ народ» (Конституція, 1996).

Отже, ефективними технологіями взаємодії громадських організацій з органами влади є: переговори, громадська експертиза; громадський моніторинг; громадський контроль; громадське розслідування; громадські ініціативи; технології судового захисту, петицій, бойкотів, 
публічних протестних акцій, PR-технології просвітницького та інформаційного забезпечення або захисту громадських інтересів та ін. Набувають поширення такі методи спільної діяльності, як контакти 3 ключовими персонами; зустрічі з громадськістю; консультаційні ради; посередництво тощо. Однією з форм громадської активності, що відіграє важливу роль у формуванні громадянського суспільства, побудові соціальної та правової держави в сучасних умовах, є волонтерська діяльність (Розвиток взаємодії, 2013, с. 164).

Слід погодитись 3 думкою П.В. Кузьміна у тому, що ефективність застосування інноваційних механізмів і технологій взаємодії інститутів влади і громадянського суспільства багато в чому залежить від ступеня взаємності, відкритості та рівня довіри (Кузьмін, 2013, с. 31).

Можна зробити висновок, що стратегічні завдання системної модернізації українського суспільства, переходу до інноваційного типу розвитку висунули на порядок денний питання про розширення конкуренції, демократії, підвищення якості соціального капіталу та довіри, а також взаємодії органів влади та громадянського суспільства. Здатність органів влади, інститутів громадянського суспільства та структур бізнесу до партнерства і консолідації в інтересах формування інституційного середовища - одна з найважливіших умов інноваційного типу розвитку. Сьогодні народжується новий тип прямої демократії - мережева демократія, яка формує середовище і механізми мобілізації для прояву активності, допомоги, захисту, громадського активізму та волонтерства, для вибудовування ефективних вертикальних і горизонтальних комунікацій в суспільстві, для акумулювання соціального капіталу та сприйняття інновацій. Інтернет-простір є важливим фактором модернізації в сучасній Україні, підвищує громадянську активність, забезпечує необхідні умови формування громадянського суспільства та інтеракцію громадянського суспільства і держави в цифровому просторі.

\section{Лimepamypa}

Белянцев А.Е., Лымар А.В. Интернет-пространство как фактор модернизации институтов гражданского общества. Вестник Нижегородского университета им. Н.И. Лобачевского. 2012. № 6 (1). С. 284-288.

Быков И.А. Электронное государство, PR и технологии Веб 2.0. PR, бизнес, СМИ - партнерство и конкуренция: Материалы VII Международной научно-практической конференции. СПб.: ИНЖЭКОН, 2010. C. $28-30$.

Гончаров И.В. Гражданский контроль за деятельностью правоохранительных органов в условиях информатизации общественных отношений. Труды Академии управления МВД России. 2019. № 3 (51). C. 21-26.

Зотова 3.М. Власть и общество: проблемы взаимодействия; под общ. ред. С. А. Попова. М.: ИКФ «Омега-Л», 2001. 352 c.

Ирхин Ю.В. Гражданское общество в современной России: управляемое, направляемое или воздействующее? Ars Administrandi. Искусство управления. 2010. № 1. С. 3-16.

Как создается и работает электронная демократия. 2018. ИЦ Региональные системы. URL: https://www.ec-rs.ru/blog/novosti/kak-sozdaetsya-i-rabotaet-elektronnaya-demokratiya/.

Конституція України від 28.06.1996 р. № 254к/96-ВР. Відомості Верховної Ради України. 1996. № 30. Ст. 141. Краснова О.Н., Зорина Н.М., Киреенкова 3.А., Кортунов В.В. Интернет как форма проявления гражданского общества. Сервис Plus. 2019. Т. 13. № 2. С. 92-98.

Кузьмин П.В. Институты власти и гражданское общество: механизмы, технологии и перспективы взаимодействия. Актуальні проблеми політики. 2013. Вип. 49. С. $22-32$.

Растимешина Т.В., Антонов Ф.С. Становление и развитие институтов гражданского общества и их взаимодействие с государством. Экономические и социально-гуманитарные исследования. 2019. № 1 (21). С. $168-179$.

Розвиток взаємодії держави і громадянського суспільства в контексті впровадження європейських принципів належного врядування: зб. матеріалів міжнар. наук.-практ. конф. (12 грудня 2012 р., м. Киї). К. : НІСД, 2013.

Томас Дж. К. Участие граждан в принятии решений органами государственного управления. Гражданское общество: пути становления: Реферат. Бюлетенъ. 2000. № 5. С. 27-42.

Фролова Т.И. Практика гражданских коммуникаций в цифровой среде: опыт систематизации. Вестник Московского университета. Серия. 10. Журналистика. 2014. № 2. С. 29-47.

Ціммерман Дж. Учасницька демократія: відродження популізму. Демократія: антологія. К.: Смолоскип, 2005. C. 263-303.

Castells M. Communication Power. Oxford: Oxford University Press, 2009. 592 p. 
Castells M. The Internet Galaxy: Reflections on the Internet, Busness and Society. Oxford: Oxford University Press, 2003. 292 p.

Castells M. The Network Society: A Cross-Cultural Perspective. Northampton, Massachusetts: Edward Elgar Publishing, 2004. 464 p.

World Internet Users Statistics and 2021. World Population Stats. URL: http://www.internetworldstats.com/ stats.htm.

\section{References}

Belyantsev A.E., Lymar A.V. Internet-prostranstvo kak faktor modernizatsii institutov grazhdanskogo obshchestva [Internet space as a factor in the modernization of civil society institutions]. Vestnik Nizhegorodskogo universiteta im. N.I. Lobachevskogo [Bulletin of the Nizhny Novgorod University]. 2012. № 6 (1). S. 284-288. [in Russian].

Bykov I.A. Elektronnoye gosudarstvo. PR i tekhnologii Veb 2.0 [Electronic government, PR and Web 2.0 technologies]. PR. biznes. SMI - partnerstvo i konkurentsiya: Materialy VII Mezhdunarodnoy nauchno-prakticheskoy konferentsii [PR, business, mass media - partnership and competition: Materials of the VII International scientific-practical conference]. SPb.: INZhEKON. 2010. S. 28-30. [in Russian].

Castells M. Communication Power. Oxford: Oxford University Press, 2009. 592 p. [in English].

Castells M. The Internet Galaxy: Reflections on the Internet, Busness and Society. Oxford: Oxford University Press, 2003. 292 p. [in English].

Castells M. The Network Society: A Cross-Cultural Perspective. Northampton, Massachusetts: Edward Elgar Publishing, 2004. 464 p. [in English].

Cimmerman Dzh. Uchasny`cz`ka demokratiya: vidrodzhennya populizmu [Participatory democracy: the revival of populism]. Demokratiya: antologiya / uporyadn. O. Procenko [Democracy: an anthology / edited. O. Protsenko]. K.: Smolosky`p, 2005. S. 263-303. [in Ukrainian].

Frolova T.I. Praktika grazhdanskikh kommunikatsiy v tsifrovoy srede: opyt sistematizatsii [The practice of civil communications in the digital environment: the experience of systematization]. Vestnik Moskovskogo universiteta. Seriya. 10. Zhurnalistika [Moscow University Bulletin. Series. 10. Journalism.]. 2014. № 2. S. 29-47. [in Russian].

Goncharov I.V. Grazhdanskiy kontrol za deyatelnostyu pravookhranitelnykh organov v usloviyakh informatizatsii obshchestvennykh otnosheniy [Civil control over the activities of law enforcement agencies in the context of informatization of public relations]. Trudy Akademii upravleniya MVD Rossii [Proceedings of the Academy of Management of the Ministry of Internal Affairs of Russia]. 2019. № 3 (51). S. 21-26. [in Russian]. Irkhin Yu.V. Grazhdanskoye obshchestvo v sovremennoy Rossii: upravlyayemoye. napravlyayemoye ili vozdeystvuyushcheye? [Civil Society in Modern Russia: Controlled, Guided or Acting?]. Ars Administrandi. Iskusstoo upravleniya [Ars Administrandi. The art of management]. 2010. № 1. S. 3-16. [in Russian].

Kak sozdayetsya i rabotayet elektronnaya demokratiya. 2018 [How e-democracy is created and works. 2018]. ITs Regionalnyye sistemy [IC Regional Systems]. URL: https://www.ec-rs.ru/blog/novosti/kak-sozdaetsya-irabotaet-elektronnaya-demokratiya/. [in Russian].

Konsty`tuciya Ukrayiny` vid 28.06.1996 r. \# 254k/96-VR [Constitution of Ukraine of June 28, 1996 № 254k / 96-VR]. Vidomosti Verxounoyi Rady' Ukrayiny` [Information of the Verkhovna Rada of Ukraine]. 1996. \# 30. St. 141. [in Ukrainian].

Krasnova O.N., Zorina N.M., Kireyenkova Z.A., Kortunov V.V. Internet kak forma proyavleniya grazhdanskogo obshchestva [Internet as a form of manifestation of civil society]. Servis Plus [Service Plus]. 2019. T. 13. № 2. S. 92-98. [in Russian].

Kuzmin P.V. Instituty vlasti i grazhdanskoye obshchestvo: mekhanizmy. tekhnologii i perspektivy vzaimodeystviya [Institutions of Power and Civil Society: Mechanisms, Technologies and Prospects for Interaction]. Aktualni problemi politiki [Actual problems of policy]. 2013. Vip. 49. S. 22-32. [in Russian].

Rastimeshina T.V., Antonov F.S. Stanovleniye i razvitiye institutov grazhdanskogo obshchestva i ikh vzaimodeystviye s gosudarstvom [Formation and development of civil society institutions and their interaction with the state]. Ekonomicheskiye $i$ sotsialno-gumanitarnyye issledovaniya [Economic, social and humanitarian research]. 2019. № 1 (21). S. 168-179. [in Russian].

Rozvy tok vzayemodiyi derzhavy i gromadyans 'kogo suspil stva v konteksti vprovadzhennya yevropejs 'ky `x pry 'ncy 'piv nalezhnogo vryaduvannya: zb. materialiv mizhnar. nauk.-prakt. konf. (12 grudnya 2012 r., m. Ky' yiv); [Development of interaction between the state and civil society in the context of implementation of European principles of good governance: coll. materials international. scientific-practical conf. (December 12, 2012, Kyiv)]. K. : NISD, 2013. [in Ukrainian].

Tomas Dzh. K. Uchastiye grazhdan v prinyatii resheniy organami gosudarstvennogo upravleniya [Citizen Participation in Government Decision Making]. Grazhdanskoye obshchestvo: puti stanovleniya: Referat. Byulleten [Civil society: ways of becoming: Abstract. Bulletin]. 2000. № 5. S. 27-42. [in Russian]. 
World Internet Users Statistics and 2021. World Population Stats. URL: http://www.internetworldstats.com/ stats.htm. [in English].

Zotova Z.M. Vlast i obshchestvo: problemy vzaimodeystviya; pod obshch. red. S. A. Popova [Power and society: problems of interaction; under total. ed. S. A. Popova.]. M.: IKF «Omega-L». 2001. 352 s. [in Russian].

\begin{abstract}
Анотація
Краснопольська Т. М., Милосердна І. М. Цифрові технології в механізмі взаємодії громадянського суспільства та держави. - Стаття.

У статті розглянуто сутність громадянського суспільства та його трансформацію в умовах активного розвитку інформаційних технологій. Визначено критерії ефективності громадянського суспільства через функції останнього. 3'ясовано роль мережі Інтернет та соціальних мереж і новітніх цифрових технологій в налагодженні та розвитку взаємодії інститутів держави та громадянського суспільства. Визначено принципи механізму взаємодії держави та громадянського суспільства та досліджено п'ять рівнів такої взаємодії, а саме: рівень комплексного аналізу проблеми, рівень розробки системи заходів і проектів програм, рівень прийняття рішень, рівень реалізації спільно прийнятого рішення та рівень контролю і перевірки виконання рішення, оцінки ефективності взаємодії сторін. Проаналізовано особливості цифрових інструментів, що використовуються на кожному рівні.

Обгрунтовано, що завдяки мережі Інтернет політичні процеси і управління набули нового змісту і зумовило появу нових суб'єктів громадянського суспільства - мережевих спільнот, які сприяють формуванню «мережевого громадянського суспільства», метою якого є спілкування в режимі он-лайн для вирішення існуючих соціальних проблем. До головних характеристик мережевого громадянського суспільства віднесені відкритість і спонтанність. Визначено, що під впливом мережевих технологій формується ореn space-простір, в якому відкриваються нові можливості для розвитку громадянського суспільства (подолання відчуженості, нерозвиненості комунікацій та ін.). Доведено, що перенесення громадських структур у віртуальний простір сприяє більш продуктивній взаємодії органів влади та громадян на основі «цифрової демократії», практичним вираженням якої стала технологія «GOV 2.0» або «уряд 2.0», яка грунтується на принципі відкритості влади та участі громадян в прийнятті рішень на всіх рівнях. Показано, що ця технологія реалізується через прихід чиновників в соціальні мережі i блогосферу, просвіту спільнот, доступ до чинних законів та законопроектів в режимі он-лайн та інші практики. 3'ясовано, що в останні роки все більшої популярності набувають такі практики, як Network Democracy («мережева демократія»), Social Bar, Global Voices Online та інші.

Ключові слова: держава, громадянське суспільство, інтеракція, інформаційні технології, цифрові технології, Інтернет.
\end{abstract}

\title{
Summary
}

Krasnopolska T. M., Myloserdna I. M. Digital technologies in the mechanism of interaction between civil society and the state. - Article.

The article considers the essence of civil society and its transformation in the conditions of active development of information technologies. Criteria for the effectiveness of civil society through the functions of the latter are defined. The role of the Internet and social networks and the latest digital technologies in the establishment and development of interaction between state and civil society institutions has been clarified. The principles of the mechanism of interaction between the state and civil society are determined and five levels of such interaction are investigated, namely: the level of complex analysis of the problem, the level of development of the system of measures and draft programs, the level of decision making, the level of joint decision implementation. Evaluation of the effectiveness of interaction between the parties. The features of digital tools used at each level are analyzed. It is substantiated that thanks to the Internet, political processes and governance have acquired a new meaning, which has led to the emergence of new actors in civil society online communities that promote the formation of "network civil society", which aims to communicate online to address existing social problems. The main characteristics of a networked civil society include openness and spontaneity. It is determined that under the influence of network technologies an open space-space is formed, in which new opportunities for the development of civil society are opened (overcoming alienation, underdeveloped communications, etc.). It has been proven that the transfer of public structures to cyberspace promotes more productive interaction between government and citizens on the basis of "digital democracy", the practical expression of which was the technology "GOV 2.0" or "government 2.0", based on the principle of open government and citizen participation. Solutions at all levels. It is shown that such technology is implemented through the arrival of officials in social networks and the blogosphere, community education, access to existing laws and bills online and other online practices. It has been found that, in addition to traditional technologies, such practices as Network Democracy, Social Bar, Global Voices Online and others have become increasingly popular in recent years.

Key words: state, civil society, interaction, information technologies, digital technologies, Internet. 